Radical News? Immigrants' Television Use, Acculturation Challenges, and Support for Terrorism

Sandy Schumann, University College London, Department of Security and Crime Science, s.schumann [@] ucl.ac.uk

Danny Osborne, University of Auckland, School of Psychology

Paul Gill, University College London, Department of Security and Crime Science

Benjamin Fell, University of Oxford, Department of Experimental Psychology

Miles Hewstone, University of Oxford, Department of Experimental Psychology 
Radical News? Immigrants' Television Use, Acculturation Challenges, and Support for Terrorism

Previous research shows that acculturation challenges predict immigrants' support for terrorism. Here, we acknowledge the central role of mass media use in the acculturation process. We investigate whether immigrants who infrequently use ethnic and host country media, a possible indicator or driver of marginalisation, report higher sympathy with terrorism than frequent media users. We further examine if those who prefer ethnic over host country media, which might reflect or facilitate disengagement from the host society, support terrorism more strongly. To address these research questions, we conducted secondary analyses of a public opinion poll of Muslim immigrants resident in the United $\operatorname{Kingdom}(N=$ 880). Focusing on immigrants' use of ethnic and host country television channels, latent class analysis identified four groups: Frequent and Infrequent Media Users as well as Ethnic and Host Country Media Users. Overall sympathy with terrorism was low. Contesting our hypothesis, Frequent Media Users supported terrorist action more than Infrequent Media Users. Ethnic Media Users also expressed higher sympathy with terrorism than Host Country Media Users. Findings emphasise the dynamic interplay between media use and acculturation challenges; they further suggest strategies to reduce immigrants' support for terrorism.

key words: ethnic media, television use, acculturation, immigrants, support for terrorism 


\section{Radical News? Immigrants' Television Use, Acculturation Challenges, and Support for Terrorism}

Public opinion polls reveal that immigrants from religious minority groups who live in the West, such as Muslims residing in non-Muslim majority countries, overwhelmingly condemn terrorism (Lugo, Cooperman, Bell, O’Connell, \& Stencel, 2013; Schmid, 2017; Wike \& Smith, 2009). The small proportion of immigrants who express positive attitudes towards terrorists' tactics and objectives (i.e., sympathy with terrorism) should not be considered radicalised or about to commit a terror attack (see Schmid, 2017). They may, however, form the radical milieu with which terrorist groups connect socially and symbolically, thus ensuring the groups' long-term survival (Malthaner, 2016; Malthaner \& Waldmann, 2014).

Previous research has demonstrated that acculturation challenges such as marginalisation, disengagement from and negative experiences with the host society predict immigrants' sympathy with terrorism (Doosje et al., 2016; King \& Taylor, 2011; LyonsPadilla, Gelfand, Mirahmadi, Farooq, \& van Egmond, 2015; Simon, Reichert, \& Grabow, 2013; Stroink, 2007). Advancing the literature, this paper prioritises the role of mass media use in the acculturation process (e.g., Ahmad, 2006; Neumann, Arendt, \& Baugut, 2018; Peeters \& d'Haenens, 2005; Jeffres, 2000). We build on the rationale that certain ethnic and host country media use practices are indicators or drivers of acculturation challenges and examine the extent to which the respective media use patterns are associated with support for terrorism.

More precisely, we investigate whether immigrants who infrequently use both ethnic and host country media, and who may be marginalised, express more support for terrorism than those who frequently rely on ethnic or host country media. In addition, we assess if 
preference for ethnic over host country media, which could reflect or facilitate disengagement from the host society, is related with a higher sympathy with terrorism. To answer these research questions, we conducted secondary analyses of a cross-sectional public opinion poll of Muslim immigrants resident in the United Kingdom. We focused on television use as a form of mass media use and drew on information about respondents' use of British and ethnic television channels as well as their sympathy with terrorist action and support of the terrorist group ISIS.

\section{Acculturation Challenges and Support for Terrorism}

In a dynamic process of acculturation, immigrants - also those in the second or third generation - decide the extent to which they adhere to the norms and values of their home country/culture, as well as how much they wish to embrace the host country/culture (e.g., Berry, 1997; Berry, Phinney, Sam, \& Vedder, 2006; Sam \& Berry, 2010). Assimilation represents a strategy whereby individuals do not maintain their home country identity but interact closely with the host society and fully adopt its values and practices. In contrast, integration entails an ongoing connection with the home country, as well as having regular contact with members of the host society and supporting its norms and values. Separation implies a strong focus on maintaining the home country identity and not engaging with the host society, whereas marginalisation encapsulates the rejection of both one's home country and host country identity (Berry, 1997).

A burgeoning body of literature points to the consequences of different acculturation strategies (e.g., Jasinskaja-Lahti, Liebkind, Solheim, 2009; Yoon et al., 2013); but few of those studies explored the relationship between acculturation and immigrants' sympathy with terrorism. Based on analyses of violent conflicts between ethnic minorities and the majority group, separation - and ensuing physical and social segregation of immigrant communities - 
has been considered as a risk factor (Cantle, 2001). Contesting this argument, those who live in homogenous ethnic communities have been found to report high trust in host country political institutions and support for democratic political engagement (Heath, Fisher, Rosenblatt, Sanders, \& Sobolewska, 2013).

Acculturation challenges, however, predict sympathy with terrorism. Notably, marginalisation was positively correlated with a perceived loss of significance, which, in turn, predicted support for terrorism (Lyons-Padilla et al., 2015). That is, Muslim immigrants in the U.S. who neither identified with their home nor their host culture reported stronger support for a radical interpretation of Islam and affirmed more strongly that others they know would sympathise with terrorist groups. Feeling that one does not matter and is not respected mediated the aforementioned relationship (Kruglanski et al., 2014). The finding corroborates research that demonstrated that a quest for personal significance strengthens the endorsement of ideologies that promise to provide a sense of belonging and meaning (uncertainty-identity theory; Hogg \& Adelman, 2013) and behaviour that advances collective values (Kruglanski \& Fishman, 2009).

Immigrants' support for terrorism is further associated with negative experiences with the host society. Perceived discrimination was positively correlated with endorsement of suicide terrorism (Victoroff, Adelman, \& Matthews, 2012); more frequent anti-Muslim protests or more votes for anti-immigrant parties were related with stronger support for ISIS amongst Muslim immigrants (Mitts, 2017). Negative experiences with members of the host country foster the justification of violence against host country representatives by facilitating disengagement from, as well as derogation of, the host society (Leyens et al., 2000; Moghaddam, 2005). Indeed, evidence from the Netherlands showed that perceived illegitimacy of host country authorities, superiority of the ethnic ingroup, distance to 
outgroups, and a sense of societal disconnection were associated with the approval of the use of violence by fellow Muslims to protect their religion (Doosje et al., 2013; see Feddes, Mann, \& Doosje, 2015). Feelings of personal uncertainty, group-based injustice, perceived threat to the ingroup's values and norms, and intergroup anxiety enhanced the aforementioned four factors of the radical belief system (Doosje et al., 2013; Doosje et al., 2016; Hogg \& Adelman, 2013; King \& Taylor, 2011).

\section{Media Use and Acculturation Challenges}

Acculturation challenges such as marginalization, negative experiences with and disengagement from the host society can be reflected in or facilitated by seemingly mundane daily practices. In this paper, we focus on immigrants' media use. We distinguish between host country and ethnic media - the latter being media that serve a certain ethnic or religious group. Considering media as an acculturation and socialisation agent, it has been posited that host country media use should facilitate the successful adaption of immigrants while ethnic media use would prompt challenges (Kim, 1988).

As immigrants engage with the host society's communication system, they get to know points of reference to inform their own and make sense of host country members' behaviour (Peeters \& d'Haenens, 2005; Tudsri \& Hebbani, 2014); they also acquire new language skills (Arnold \& Schneider, 2007; Reece \& Palmgreen, 1996). Frequent host country media use was further correlated with a stronger willingness to engage in close social interactions with host country members (Dalisay, 2012; Shah, 1991), the acceptance of host society values (Moon \& Park, 2010), as well as the salience of host society identity (Cheah, Karamehic-Muratovic, Matsuo, \& Poljarevic, 2011; Croucher, Oommen, Borton, Anarbaeva, \& Turner, 2010). Furthermore, Arnold and Schneider (2007) highlighted that the German- 
resident Turkish respondents in their study who used only German media felt close to Germany, had weak ties with Turkish identity, and supported integration.

A study of Russian immigrants and members of the Arab minority in Israel distinguished four types of media users: dualists, adapters, separatists, and detached (Adoni, Cohen, \& Caspi, 2002). The authors showed that amongst Russian immigrants, separatists, defined by infrequent use of majority but frequent use of minority language media, were most common, followed by dualists who frequently used minority and majority language media. For the respondents from the Arab minority, dualists were most common. In both groups, only a small number of respondents were characterised as adapters - high use of majority but low use of minority language media - and detached - low use of either minority or majority media. Importantly, majority language media use was associated with a stronger identification with the Israeli majority group; minority language media use predicted stronger identification with the respective minority group (Adoni et al., 2002).

A panel study with 11 different immigrant groups in the US confirmed the latter result and demonstrated that ethnic media use enhanced the strength of immigrants' ethnic identity and participation in activities related to the ethnic ingroup (Jeffres, 2000). Those who preferred ethnic media were also less actively engaged with the host society, interacted less frequently with host country members (Dalisay, 2012), and preferred separation as an acculturation style (Arnold \& Schneider, 2007). Park, Song, and Lee (2014) further showed that for East Asian exchange students in the United States use of social network sites that were popular in the home but not the host country was positively related with acculturation stress (see as well Melkote \& Liu, 2000). Using the internet in one's native, rather than the host country, language was as well positively correlated with experiences of cultural shock (Ye, 2005). 
Having said this, ethnic media use can also serve as a means to cope with acculturation stress, in particular in the early stages of the acculturation process and when used in combination with host country media (Walker, 1999). Ethnic media provides immigrants with the opportunity to maintain (or form) a connection with their country and culture of origin, preserving the language spoken 'at home' (e.g., Ahmad, 2006; Jeffres, 2000; Vishwanath \& Arora, 2000). Ethnic media use grants an experience of comfort and familiarity and, therefore, may be relied on in response to the under- or misrepresentation of immigrants or religious communities in host country media (Harwood \& Anderson, 2002; Mastro \& Behm-Morawitz, 2005; Sobolewska \& Ali, 2012).

\section{The Present Research}

Our study aims to bring together insights on immigrants' media practices, acculturation challenges, and support for terrorism to examine whether certain patterns of ethnic and host country media use are associated with sympathy for terrorist action and groups. As aforementioned, frequent host country and ethnic media use predict engagement and identification with the host or home culture. Infrequent host country and ethnic media use thus should indicate or evoke low identification with both the host and home culture, reflecting immigrants' marginalisation. We therefore postulate (Hypothesis 1): Immigrants who use both ethnic and host country media infrequently report stronger support for terrorism than those who use either one or both types of media frequently.

Moreover, host country media use has been found to predict frequent interactions with host country members, it fosters salience of host country identity, as well as a preference for integration. In turn, previous research showed that ethnic media use is related with stronger identification with one's ethnic group and culture shock. Disengagement from the host country should then be evidenced in or fostered by a lower preference of host country media 
and higher use of ethnic media. Hence, we hypothesise (Hypothesis 2): Immigrants who prefer host country over ethnic media express less support for terrorism than immigrants who prefer ethnic over host country media.

These hypotheses have to our knowledge not yet been assessed. Results from the 2002 Gallup Poll of the Islamic World, conducted in nine predominantly Muslim countries, however, showed that respondents who solely received news from Al Jazeera were significantly less likely to consider the $9 / 11$ terror attacks in the U.S. as unjustifiable (Gentzkow \& Shapiro, 2004; see as well El Nawawy \& Powers, 2008; Nisbet \& Myers, 2011). The same relationship existed for respondents who relied on CNN and Al Jazeera; there was no significant association between watching $\mathrm{CNN}$ and the justification of 9/11. Relatedly, Al-Mutafy (2012) examined public opinion during the second Palestinian Intifada. The large majority (92\%) of Arab speaking participants believed that the television coverage from Al Jazeera provoked their anger towards the Second Intifada.

\section{Method}

\section{Design and Sample}

We performed secondary analyses of data from a cross-sectional public opinion poll. The purposive sample of 1081 respondents were resident in the United Kingdom (UK) at the time of data collection. The analytical sample used for hypotheses testing was comprised of 880 respondents $(81.4 \%$ of the full sample); these are respondents who had affirmed that they used television, including digital channels, to receive information about news and current affairs and who then reported detailed information about ethnic and host country television use.

Respondents' median age was 35-44 years (53.1\% men; 68.5\% married; 51.6\% worked full-time or part-time). All respondents described themselves as being Muslim and were of Pakistani (54.8\%), Bangladeshi (18.4\%), African (10.2\%), Indian (6.4\%), Asian 
otherwise unspecified (3.8\%), and Arab (1.0\%) descent or described themselves as either mixed, other Black/African/Caribbean, White or 'other' ethnicity (total 5.4\%). The majority of the respondents, $55.9 \%$, were not born in the UK; $30.5 \%$ were born in the UK, but their parents were not; $12.4 \%$ respondents can be characterised as 'third-generation and above' immigrants (i.e., they themselves and their parents were born in the UK).

\section{Procedure}

Data were collected by ICM Unlimited, commissioned by the British television channel Channel 4. Data were in part presented in a programme on Channel 4 (to the best of our knowledge, the data were not presented elsewhere). Data were made available to the last author for further analyses upon request and after permission to release the raw data was obtained.

Respondents were sampled using a representative random location, quota-based approach, focusing on lower super output areas (LSOAs) with at least 20\% Muslim populations (as documented in the 2011 UK census). These 2014 LSOAs were home to $51 \%$ of the Muslim population in the UK. The sample size was further reduced to 138 LSOAs. The precise sampling locations are available online ${ }^{1}$. Computer-assisted personal interviews were conducted in the spring of 2015. Data were weighted by age, gender, work status, and government office region in the UK.

\section{Measures}

Our analyses are based on a selection of the variables that were asked in the original survey. Below we state all measures that we used to test our hypotheses. Additional measures that were included in supplementary analyses are reported in the Supplementary Material. All response options are indicated; response options 'Prefer not to say' and 'Don't know' were

\footnotetext{
${ }^{1}$ https://www.icmunlimited.com/wp-content/uploads/2016/04/Survey-of-Muslims_Sampling-approach.pdf
} 
coded as missing values.

Media use was assessed by asking all respondents to indicate which media (television, British newspaper, Foreign newspaper, Internet news websites, social media, radio) they used to receive information about news and current affairs $(0=N o ; 1=$ Yes $)$. Respondents who affirmed that they used television then reported which of the following channels they regularly watched to receive news $(0=N o ; 1=Y e s)$ : (1) BBC 1, (2) BBC 2, (3) BBC News, (4) ITV News, (5) Channel 4, (6) Channel 5, (7) Sky News, (8) Islam Channel, (9) Peace TV, (10) ARY News, (11) PTV Global, and (12) PTV Prime. The first seven channels are host country, British, television channels; we operationalised the latter five channels as ethnic media. Islam Channel broadcasts English-language programmes about religious topics. Peace TV is an Islamic international TV channel available in English, Bengali, and Urdu. In the UK, Peace TV was issued a penalty for breach of content code in 2016. ARY News is a bilingual (English/ Urdu) news channel. PTV Global covers Pakistani news and current affairs. PTV Prime is a British-Asian entertainment channel that targets the British Pakistani community.

In order to investigate support for terrorism, we examined the extent to which respondents sympathised with, or condemned, terrorist activities for political protest ('Use violence in political protest', 'Make threats of terrorist actions as part of political protest', 'Organise radical groups, but do not take part in terrorist actions', 'Commit terrorist actions as a form of political protest'; 1 = completely sympathise $; 5$ = completely condemn; reverse-coded; $\alpha=$ .91). We also assessed support for, or opposition to, the terrorist organisation ISIS ('To what extent do you support or oppose the objective to create an Islamic state?', 'And to what extent do you support or oppose the way in which Islamic State/ISIS/ISIL is trying to establish a Caliphate?'; 1 = strongly support; 5 = strongly oppose; reverse-coded; $\alpha=.88$ ).

\section{Results}




\section{Descriptive Statistics}

Table 1 displays descriptive statistics and bivariate correlations for the central variables used in this study. The majority of respondents stated that they relied on television to receive information about current affairs (81.4\%). Social media (37.4\%) and internet news websites (34\%) were fairly popular as well, as were British newspapers (30.6\%). Foreign newspapers $(8.5 \%)$ and radio $(9.5 \%)$ were only used by a small number of respondents. Support for terrorism was overall low. In addition, no systematic differences in support for terrorist action and groups was identified between respondents from different immigrant generations, different ethnicities, age groups, or female and male respondents (Supplementary Material S1, Table S1).

— Insert Table 1 here-

\section{Analytical Approach}

The hypotheses imply that we investigate how certain 'types of people' - who report distinct media use patterns - differ from other 'types of people' in their support for terrorism. It is therefore appropriate to follow a person-centred analytical approach and conduct a latent class analysis (LCA). Doing so, sub-groups of respondents with unique response patterns on the items that examine ethnic and host country television use are identified (see Osborne \& Sibley, 2017). One key advantage of LCAs is that we do not need to create arbitrary cut-off points on the independent variables to decide which respondent is considered to be using different media (in)frequently (see Adoni et al., 2002).

\section{Patterns of Television Use}

All analyses were completed using Mplus version 8.0 (Muthén \& Muthén, 1998-2017). We sequentially estimated models containing between one and nine-class solutions, corresponding to one to nine (the number of all assessed channels) potential groups of 
respondents with unique television use practices. Model fit initially improved with the addition of each subsequent class (based on the Akaike Information Criterion (AIC) and samplesize adjusted Bayesian Information Criterion (BIC); Table 2). Although the Lo-Mendell-Rubin (LMR; adjusted likelihood ratio) test also showed that model fit significantly improved with the addition of each subsequent class, entropy - indicating the uncertainty of assigned class membership (see Collins \& Lanza, 2010) - declined when moving from a model with four to five classes. The BIC also plateaued at five classes, and model fit declined with the addition of each class thereafter (see Supplementary Material S2, Table S2). A four-class solution provided the best fit to our data, considering both statistical criteria and model parsimony. --Insert Table 2 here--

We then examined the estimated probability of watching a given television channel as a function of the most likely membership in one of the four latent classes. Figure 1 shows that those who belonged to Class 1 - labelled Frequent Media Users - had consistently a high probabilities of watching each of the channels included in the analysis. Only $4 \%$ of the sample belonged to this class. The second latent class was by far the most numerous $-77.6 \%$ of the sample - and was characterised by low levels of television usage (i.e., Infrequent Media Users). Except for BBC1 viewership (Probability $\mid \mathrm{BBC} 1=.656, S E=.02, p<.001$ ), respondents who belonged to this class were more likely to not watch any of the assessed channels to receive news. Respondents who belonged to Class 3 were Ethnic Media Users $(2.8 \%$ of the sample). They expressed low levels of British news outlet usage, but they were particularly attuned to ARY News (Probability $\mid$ ARY News $=.753, S E=.12, p<.001)$, PTV Global $($ Probability $\mid$ PTV Global $=.690, S E=.17, p<.001)$, and PTV Prime $($ Probability $\mid$ PTV Prime $=.827, S E=.13, p<.001$ ). Finally, $15.6 \%$ of the sample belonged to Class 4 (i.e., Host Country Media Users); they were more likely than not to watch each of the seven British 
news channels but reported low levels of engagement with the ethnic media.

--Insert Figure 1 here--

\section{Television Use Patterns and Support for Terrorism}

Following, we investigated whether support for terrorism was a function of most likely class membership; this method takes into account the large differences in class size (Table 3). Support for terrorist action as a form of political protest varied across all classes, $\chi^{2}(3)=$ 25.20. Respondents who were most likely to be in the Frequent Media User class expressed more support for terrorist action than those in the Infrequent Media User class, $\chi^{2}(1)=12.50$, $p<.001$. There was no difference in support for terrorist action between respondents who belonged to the Ethnic Media User class and the Infrequent Media User class, $\chi^{2}(1)=1.42, p=$ .234. Those most likely to infrequently consume any of the assessed television channels for news, however, supported terrorist action more so than respondents who most likely belonged to the Host Country Media User class, $\chi^{2}(1)=9.17, p=.002$. Hypothesis 1 must be rejected.

Consistent with Hypothesis 2, those most likely to be in the Ethnic Media User class expressed greater mean levels of support for terrorist action than those who belonged to the Host Country Media User class, $\chi^{2}(1)=4.00, p=.013$. At the same time, respondents' in the Frequent Media User class did not differ significantly in terms of their support for terrorist action from those in the Ethnic Media User class, $\chi^{2}(1)=3.42, p=.065$. Further exploratory analysis showed that Frequent Media Users supported terrorist action more so than Host Country Media Users, $\chi^{2}(1)=19.86, p<.001$.

Support for ISIS also varied by most likely class membership, $\chi^{2}(3)=10.02, p=.018$. Those in the Ethnic Media User class reported stronger support for ISIS than those in the Infrequent Media User class, $\chi^{2}(1)=7.40, p=.007$, and the Host Country Media User class, $\chi^{2}(1)=8.39, p=.004$. None of the other class differences were significant, $\chi^{2}(1) \leq 2.32, p \geq$ 
.128. These results are also inconsistent with Hypothesis 1 but in line with Hypothesis 2.

-- Insert Table 3 here-

Lastly, exploratory analyses were conducted to examine the demographic characteristics and attitudes of users in the four media use classes. Results are presented in the Supplementary Material S3, Table S3.1-S3.2.

\section{Discussion}

Since the 9/11 terror attacks in the United Sates, a burgeoning body of research has assessed individual-, group- and macro-level factors that predict or explain why individuals commit acts of terrorism (Atran, 2016; Horgan, 2008; Moghaddam, 2005). Somewhat less attention has been paid to those who express sympathy with - but do not voice intentions to engage in - terrorist activities. Our study addressed this oversight and investigated how Muslim immigrants who reported distinct patterns of ethnic and host country television use differed in their support for terrorism. Consistent with past research (e.g., see Arnold \& Schneider, 2007; Shah, 1991), our analyses showed that immigrants received overall more news from host country than ethnic channels. Furthermore, mean levels of support for terrorism were low. This latter result resonates with studies that have highlighted that British Muslims have high trust in the UK government and are civic-minded, which stands in stark contrast to the use of violence in political protest (Heath et al., 2013; Sanders, Heath, Fisher, \& Sobolewska, 2014; Maxwell, 2010).

\section{Infrequent Media Use and Support for Terrorism}

Advancing the literature, we demonstrated that respondents who frequently used both British and ethnic channels to access news expressed more sympathy with terrorist action than those who infrequently consumed these television channels. Consequently, we had to reject the hypothesis that infrequent use of ethnic or host country media - thought to be associated 
with marginalization - predicts stronger support for terrorism. This unexpected result may be explained by Frequent Media Users' exposure to conflicting (and derogatory) information (see Gentzkow \& Shapiro, 2004).

Our study only captured the television channels that Muslim immigrants used to get news; we do not know what specific content respondents consumed. It is conceivable, though, that immigrants who used host country as well as ethnic media frequently were confronted with information about the same issue that is presented from different perspectives - that of the host and home country. Issues pertaining to host-home country relations or reports about atrocities that host country representatives may have committed in the home country could be framed from opposing angles. Third parties might be portrayed as an enemy of the host country, but as an ally of the home country. Moreover, ethnic and host country media may portrait the immigrant's ethnic and religious communities differently. Muslims in particular are presented as more negative than the majority group in Western media (Downing \& Husband, 2005). Muslims are frequently associated with terrorism and cultural deviation, that is, media reporting frequently emphasises that Muslim immigrants and British people hold opposing values (Poole, 2002; Sobolewska \& Ali, 2012).

Being exposed to conflicting perspectives or information that states that Muslim and non-Muslim British are different may evoke experiences of a clash between the home and host country identity, between the values of these two cultures. Identity conflict, in turn, predicts support for radical action and terrorist activities. Previous research demonstrated that if home and host country identities were thought to be at conflict, immigrants in Germany were more willing to engage in illegal activities to bring about justice (Simon et al., 2013). For Muslims and Christians in Lebanon and Syria, a perceived clash between Arab and American 
values correlated positively with support for fundamentalist groups and attacks on American targets (Sidanius, Kteily, Levin, Pratto, \& Obaidi, 2015).

\section{Host Country Media Preference and Support for Terrorism}

In line with our hypothesis, respondents in the Host Country Media User class expressed less support for terrorist action and ISIS than those in the Ethnic Media User class. Correlates of the Host Country Media Use class (Supplementary Material S3, Table S3.2) suggest that these respondents were more engaged with, and held more positive views of, their life in the UK than Ethnic Media Users (Arnold \& Schneider, 2007). In turn, the more immigrants believed that the quality of life for Muslims in the UK was low, the more likely they were to prefer ethnic media. Considering these findings, it is tempting, but wrong, to state that host country media use serves as a buffer against immigrants' support for terrorism. First, the data does not allow causal conclusions about media effects, a point that is discussed in more detail below. Second, those who consumed British media in addition to ethnic media did not report significantly lower levels of sympathy with terrorist action than Ethnic Media Users. Third, given that reporting about Muslims in Western media is often negative, its potential contribution to acculturation challenges must be accounted for. Notably, Neumann and colleagues (2018) showed in an interview study that Muslims in Germany viewed the news reporting about Islam in German media overall as negative. A follow-up experiment demonstrated that exposure to such negative news coverage elicited feelings of anger as well as the perception that host country representatives would be (negatively) affected in their views about Islam. The latter result is especially concerning as it could point to expectations of discrimination and negative experiences with the host society. 


\section{Reducing Support for Terrorism}

Despite the aforementioned qualifications, our findings do point out that strong engagement with the host society is correlated with less support for terrorist action and groups (Supplementary Material S3, Table S3.1). Initiatives that enable immigrants' social integration and successful adaption are therefore undoubtedly crucial to reduce sympathy with terrorism. Importantly, results emphasise that reporting about immigrant communities in host country media that conflicts with the groups' self-perception may evoke sentiments that contribute to increased support for terrorism. Hence, biased reporting about ethnic and religious minorities must be adjusted to reflect the diverse voices and attitudes of immigrants rather than focus on a selected view that corresponds with expected, negative stereotypes (Sobolewska \& Ali, 2012). Moreover, ethnic media could play a role in fostering immigrants' successful adaption by providing content that facilitates successful life in the host country, e.g., information about customs or habit, and promotes active engagement with host country members. Doing so, host country and ethnic media might be able to help alleviate acculturation challenges as well as reduce the likelihood that immigrants come to support terrorism.

\section{Media and Selection Effects}

It may be tempting to interpret the results of this study as media effects, i.e., that certain media use practices facilitate support for terrorism. However, given the cross-sectional design of the survey, we are unable to distinguish exposure from media selection effects. For instance, rather than frequent host country and ethnic media use facilitating support for terrorism, individuals who sympathise with terrorist action might be more aware of the grievances of particular groups, which could foster information seeking across various channels. Predominant host country media use may foster lower levels of acculturation challenges, better language skills, and more engagement with the host society, but could also be the result of immi- 
grants having (already) established close bonds with host country representatives. That is, while we can document an interplay between acculturation challenges and media use patterns, we can not specify the direction of the relationship. Therefore, we also cannot specify causes of support for terrorism. To address this limitation, we encourage researchers to pursue our research questions with longitudinal designs and diary studies.

\section{Limitations and Future Research}

In addition, social desirability likely affected responses (and reduced variability) on the outcome variables. The fact that we nevertheless identified differences between classes speaks to the strength of our findings. We are, however, not able to generalise the findings to all Muslim immigrants living in the UK or elsewhere (Haque, 2018). The sampling strategy used in the study focused on immigrants who lived in areas with at least $20 \%$ of Muslim population. Living in an area with a relatively high concentration of fellow Muslims may be an expression of certain acculturation preferences, or may increase the risk of acculturation challenges, such as feeling disengaged from the host country.

Moreover, our analyses explored only ethnic and host country television news consumption as one form of media use. This narrow scope seemed justified as the majority of respondents reported relying on television to receive news. Nevertheless, as proposed by Park, Song, and Lee (2014), in order to capture the role of media for acculturation, and by extension related phenomena, traditional and new media ought to ideally be considered together. Doing so is also crucial as immigrants are likely exposed to different types of content on television and social media. Notably, it has been shown that extreme anti-immigrant views are in recent years more prevalent on social media (Lee \& Littler, 2015) - right-wing groups use social media to avoid the cordon sanitaire that prevents them from voicing their ideas on traditional media (Littler \& Feldman, 2017). Exposure to anti-immigrant content can foster feelings of 
perceived discrimination, which, in turn, may facilitate support for terrorism (Baugut \& Neumann, 2019). Future research should therefore assess a wider variety of media, notably, types of social media use, as immigrants likely combine information from ethnic and host country sources across the hybrid media system. Lastly, content analyses of media are crucial to begin to explain why distinct media use patterns are associated with stronger support for terrorism.

Despite these limitations, we believe that our study makes an important contribution to the literature, and we hope it will initiate a new line of interdisciplinary inquiry. We showed that immigrants who frequently use ethnic and host country mass media as well as those who prefer ethnic media express elevated levels of sympathy with terrorist action and groups. Going forward, and as the underlying processes of these relationships are examined, new avenues to reduce immigrants' support for terrorism can be developed. 


\section{References}

Ahmad, F. (2006). British Muslim perceptions and opinions on news coverage of September 11. Journal of Ethnic and Migration Studies, 32(6), 961-982. DOI:

10.1080/13691830600761479

Al-Mutafy, M.R. (2012). Al Jazeera and the second intifada: War, Media and Public Opinion. LAP LAMBERT Academic Publishing.

Arnold, A. K., \& Schneider, B. (2007). Communicating separation? Ethnic media and ethnic journalists as institutions of integration in Germany. Journalism, 8(2), 115-136. DOI: $10.1177 / 1464884907074807$

Asparouhov, T., \& Muthén, B. (2014). Auxiliary variables in mixture modeling: Three-step approaches using Mplus. Structural Equation Modeling: A Multidisciplinary Journal, 21(3), 329-341. DOI: 10.1080/10705511.2014.915181

Atran, S. (2016). The devoted actor: Unconditional commitment and intractable conflict across cultures. Current Anthropology, 57(13), 192-203. DOI: 10.1086/685495

Baugut, P., \& Neumann, K. (2019). Online news media and propaganda influence on radicalized individuals: Findings from interviews with Islamist prisoners and former Islamists. New Media \& Society, DOI: 10.1177/1461444819879423.

Berry, J. W. (1997). Immigration, acculturation, and adaptation. Applied Psychology, 46(1), 5-34. DOI: $10.1177 / 1464884907074807$

Berry, J. W., Phinney, J. S., Sam, D. L., \& Vedder, P. (2006). Immigrant youth: Acculturation, identity, and adaptation. Applied psychology, 55(3), 303-332. DOI: 10.1111/j.1464-0597.2006.00256.x

Cantle, T. (2001). Community Cohesion: Report of the Independent Review Team - The 'Cantle Report'. London: Home Office.

Cheah, W. H., Karamehic-Muratovic, A., Matsuo, H., \& Poljarevic, A. (2011). The role of language competence, interpersonal relationships, and media use in Bosnian refugees' resettlement process. Journal of Intercultural Communication Research, 40(3),

219-236. DOI: 10.1080/17475759.2011.618842

Collins, L. M., \& Lanza, S. T. (2010). Latent class and latent transition analysis: With applications in the social, behavioral, and health sciences. New York, USA: Wiley.

Croucher, S. M., Oommen, D., Borton, I., Anarbaeva, S., \& Turner, J. S. (2010). The influence of religiosity and ethnic identification on media use among Muslims and non-Muslims in France and Britain. Mass Communication and Society, 13(3), 314-334. DOI: 10.1080/15205430903296085

Dalisay, F. (2012). Media use and acculturation of new immigrants in the United States. Communication Research Reports, 29(2), 148-160. DOI: 10.1080/08824096.2012.667774

Doosje, B., Loseman, A., \& Van Den Bos, K. (2013). Determinants of radicalization of Islamic youth in the Netherlands: Personal uncertainty, perceived injustice, and perceived group threat. Journal of Social Issues, 69(3), 586-604. DOI: 10.1111/josi. 12030

Doosje, B., Moghaddam, F. M., Kruglanski, A. W., De Wolf, A., Mann, L., \& Feddes, A. R. (2016). Terrorism, radicalization and de-radicalization. Current Opinion in Psychology, 11, 79-84. DOI: 10.1016/j.copsyc.2016.06.008

Downing, J. D., \& Husband, C. (2005). Representing race: Racisms, ethnicity and the media. 
London: Sage Publications Ltd.

El-Nawawy, M., \& Powers, S. (2008). Mediating conflict: Al-Jazeera English and the possibility of a conciliatory media. Los Angeles: Figueroa press. Retrieved from http://stage. uscpublicdiplomacy. org/sites/uscpublicdiplomacy. org/files/useruploads/ u22281/AJERP\% 2520el\% 2520Nawawy, 2520, 2526.

Feddes, A. R., Mann, L., \& Doosje, B. (2015). Increasing self-esteem and empathy to prevent violent radicalization: a longitudinal quantitative evaluation of a resilience training focused on adolescents with a dual identity. Journal of Applied Social Psychology, 45(7), 400-411. DOI: 10.1111/jasp.12307

Ganor, B. (2011). An intifada in Europe? A comparative analysis of radicalization processes among Palestinians in the West Bank and Gaza versus Muslim immigrants in Europe.

Studies in Conflict \& Terrorism, 34(8), 587-599. DOI: 10.1080/1057610X. 2011.582629

Haque, Z. (2018). The one poll on British Muslims which is worth reading. iNews, Available at: https://inews.co.uk/opinion/comment/muslims-poll-ipsos-mori/

Harwood, J., \& Anderson, K. (2002). The presence and portrayal of social groups on primetime television. Communication Reports, 15(2), 81-97. DOI: 10.1080/08934210209367756

Heath, A. F., Fisher, S. D., Rosenblatt, G., Sanders, D., Sobolewska, M. (2013). The Political Integration of Ethnic Minorities in Britain. Oxford: Oxford University Press.

Hogg, M. A., \& Adelman, J. (2013). Uncertainty-identity theory: Extreme groups, radical behavior, and authoritarian leadership. Journal of Social Issues, 69(3), 436-454. DOI:

$10.1111 /$ josi.12023

Horgan, J. (2008). From profiles to pathways and roots to routes: Perspectives from psychology on radicalization into terrorism. The ANNALS of the American Academy

of Political and Social Science, 618(1), 80-94. DOI: 10.1177/0002716208317539

Jasinskaja-Lahti, I., Liebkind, K., \& Solheim, E. (2009). To Identify or Not To Identify? National Disidentification as an Alternative Reaction to Perceived Ethnic

Discrimination. Applied Psychology, 58(1), 105-128. DOI: 10.1111/j.

1464-0597.2008.00384.x

Jeffres, L. W. (2000). Ethnicity and ethnic media use: A panel study. Communication Research, 27(4), 496-535. DOI: 10.1177/009365000027004004

Kim, Y. (1988). Communication and Cross-cultural Adaption. Philadelphia, USA: Multilingual Matter Ltd.

King, M., \& Taylor, D. M. (2011). The radicalization of homegrown jihadists: A review of theoretical models and social psychological evidence. Terrorism and Political Violence, 23(4), 602-622. DOI: 10.1080/09546553.2011.587064

Kruglanski, A. W., \& Fishman, S. (2009). Psychological factors in terrorism and counterterrorism: Individual, group, and organizational levels of analysis. Social Issues and Policy Review, 3(1), 1-44. DOI: 10.1111/j.1751-2409.2009.01009.x

Kruglanski, A. W., Gelfand, M. J., Bélanger, J. J., Sheveland, A., Hetiarachchi, M., \& Gunaratna, R. (2014). The psychology of radicalization and deradicalization: How significance quest impacts violent extremism. Political Psychology, 35, 69-93. DOI: 10.1111/pops. 12163

Lee, B., \& Littler, M. (2015). Viral advertising and new pathways to engagement with the British National Party. The Journal Of Political Criminology, 1(1). 
Littler, M., \& Feldman, M. (2017). Social media and the cordon sanitaire: Populist politics, the online space, and a relationship that just isn't there. Journal of Language and Politics, 16(4), 510-522. DOI: 10.1075/jlp.17029.lit

Lyons-Padilla, S., Gelfand, M. J., Mirahmadi, H., Farooq, M., \& Van Egmond, M. (2015). Belonging nowhere: Marginalization \& radicalization risk among Muslim immi grants. Behavioral Science \& Policy, 1(2), 1-12. DOI: 10.1353/bsp.2015.0019

Malthaner, S. (2014). Contextualizing radicalization: The emergence of the "SauerlandGroup" from radical networks and the Salafist movement. Studies in Conflict \& Terrorism, 37(8), 638-653. DOI: 10.1080/1057610X.2014.921767

Malthaner, S., \& Waldmann, P. (2014). The radical milieu: Conceptualizing the supportive social environment of terrorist groups. Studies in Conflict \& Terrorism, 37(12), 979-998. DOI:10.1080/1057610X.

Mastro, D. E., \& Behm-Morawitz, E. (2005). Latino representation on primetime television. Journalism \& Mass Communication Quarterly, 82(1), 110-130. DOI: $10.1177 / 107769900508200108$

Maxwell, R. (2010). Trust in government among British Muslims: The importance of migration status. Political Behavior, 32(1), 89-109. DOI: 10.1007/s11109-009-9093-1

Melkote, S. R., \& Liu, D. J. (2000). The role of the internet in forging a pluralistic integration: A study of Chinese intellectuals in the United States. International Communication Gazette, 62(6), 495-504. DOI: 10.1177/0016549200062006003

Mitts, T. (2017). From Isolation to Radicalization: Anti-Muslim Hostility and Support for ISIS in the West. Available at: https://papers.ssrn.com/sol3/papers.cfm? abstract_id $=2795660$

Moghaddam, F. M. (2005). The staircase to terrorism: A psychological exploration. American Psychologist, 60(2), 161-169. DOI: 10.1037/0003-066X.60.2.161

Moon, S. J., \& Park, C. Y. (2007). Media effects on acculturation and biculturalism: A case study of Korean immigrants in Los Angeles' Koreatown. Mass Communication and Society, 10(3), 319-343. DOI: 10.1080/15205430701407330

Muthén, L.K. and Muthén, B.O. (1998-2017). Mplus User's Guide. Eighth Edition. Los Angeles, CA: Muthén \& Muthén.

Neumann, K., Arendt, F., \& Baugut, P. (2018). News and Islamist radicalization processes: Investigating Muslims' perceptions of negative news coverage of Islam. Mass Communication and Society, 1-26. DOI: 10.1080/15205436.2018.1430832

Nisbet, E. C., \& Myers, T. A. (2011). Anti-American sentiment as a media effect? Arab media, political identity, and public opinion in the Middle East. Communication Research, 38(5), 684-709.

Osborne, D., \& Sibley, C. G. (2017). Identifying "types" of ideologies and intergroup biases: Advancing a person-centred approach to social psychology. European Review of Social Psychology, 28(1), 288-332. DOI:10.1080/10463283.2017.137926

Park, N., Song, H., \& Lee, K. M. (2014). Social networking sites and other media use, acculturation stress, and psychological well-being among East Asian college students in the United States. Computers in Human Behavior, 36, 138-146. DOI: 10.1016/j.chb.2014.03.037

Peeters, A. L., \& d'Haenens, L. (2005). Bridging or bonding? Relationships between 
integration and media use among ethnic minorities in the Netherlands. The European Journal of Communication Research, 330(2), 201-231. DOI: 10.1515/comm.

2005.30.2.201

Poole, E. (2002). Reporting Islam: Media Representations of British Muslims. London: Bloomsbury Publishing.

Reece, D., \& Palmgreen, P. (2000). Coming to America: Need for acculturation and media use motives among Indian sojourners in the US. International Journal of Intercultural Relations, 24(6), 807-824. DOI: 10.1016/S0147-1767(00)00033-X

Sam, D. L., \& Berry, J. W. (2010). Acculturation: When individuals and groups of different cultural backgrounds meet. Perspectives on Psychological Science, 5(4), 472-481.

DOI: $10.1177 / 1745691610373075$

Sanders, D., Fisher, S. D., Heath, A., \& Sobolewska, M. (2014). The democratic engagement of Britain's ethnic minorities. Ethnic and Racial Studies, 37(1), 120-139. DOI: 10.1080/01419870.2013.827795

Schmid, A. P. (2017). Public Opinion Survey Data to Measure Sympathy and Support for Islamist Terrorism: A Look at Muslim Opinions on Al Qaeda and IS. ICCT Research Paper. Available at: https://icct.nl/wp-content/uploads/2017/02/ICCT-

Schmid-Muslim-Opinion-Polls-Jan2017-1.pdf

Shah, H. (1991). Communication and cross-cultural adaptation patterns among Asian Indians. International Journal of Intercultural Relations, 15(3), 311-321. DOI: 10.1016/0147-1767(91)90004-Z

Sidanius, J., Kteily, N., Levin, S., Pratto, F., \& Obaidi, M. (2016). Support for asymmetric violence among Arab populations: The clash of cultures, social identity, or counterdominance? Group Processes \& Intergroup Relations, 19(3), 343-359. DOI:

$10.1177 / 1368430215577224$

Simon, B., Reichert, F., \& Grabow, O. (2013). When dual identity becomes a liability: Identity and political radicalism among migrants. Psychological Science, 24(3), 251-257. DOI: 10.1177/0956797612450889

Sobolewska, M., \& Ali, S. (2015). Who speaks for Muslims? The role of the press in the creation and reporting of Muslim public opinion polls in the aftermath of London bombings in July 2005. Ethnicities, 15(5), 675-695. DOI: 10.1177/1468796812467958

Stroink, M. L. (2007). Processes and preconditions underlying terrorism in second-generation immigrants. Peace and Conflict: Journal of Peace Psychology, 13(3), 293-312. DOI:

10.1080/10781910701471322

Tudsri, P., \& Hebbani, A. (2015). 'Now I'm Part of Australia and I Need to Know What Is Happening Here': Case of Hazara Male Former Refugees in Brisbane Strategically Selecting Media to Aid Acculturation. Journal of International Migration and Integration, 16(4), 1273-1289. DOI: 10.1007/s12134-014-0373-1

Victoroff, J., Adelman, J. R., \& Matthews, M. (2012). Psychological factors associated with support for suicide bombing in the Muslim diaspora. Political Psychology, 33(6), 791-809. DOI: 10.1111/j.1467-9221.2012.00913.x

Viswanath, K., \& Arora, P. (2000). Ethnic media in the United States: An essay on their role in integration, assimilation, and social control. Mass Communication and Society,

3(1), 39-56. DOI: 10.1207/S15327825MCS0301_03

Walker, D. (1999). The media's role in immigrant adaptation: How first-year Haitians in Miami use the media. Journalism \& Communication Monographs, 1(3), 158-196. 
DOI: $10.1177 / 152263799900100301$

Wike \& Smith, G. (2009). Little Support for Terrorism Among Muslim Americans. Pew Research Center. Available at: http://www.pewforum.org/2009/12/17/little-supportfor-terrorism-among-muslim-americans/

Ye, J. (2005). Acculturative stress and use of the Internet among East Asian international students in the United States. CyberPsychology \& Behavior, 8(2), 154-161. DOI: 10.1089/cpb.2005.8.154

Yoon, E., Chang, C. T., Kim, S., Clawson, A., Cleary, S. E., Hansen, M., ... \& Gomes, A. M. (2013). A meta-analysis of acculturation/enculturation and mental health. Journal of Counseling Psychology, 60(1), 15-30. DOI: 10.1037/a0030652 


\section{Tables}

Table 1. Descriptive statistics of independent and dependent variables.

\begin{tabular}{|c|c|c|c|c|c|}
\hline & $M$ & $S D$ & $N$ & 1 & 2 \\
\hline $\begin{array}{l}\text { 1. Support for Terrorist } \\
\text { Action }\end{array}$ & 1.57 & .83 & 860 & 1 & \\
\hline \multirow[t]{2}{*}{ 2. Support for ISIS } & 1.60 & .93 & 798 & $.37 * * *$ & 1 \\
\hline & $\begin{array}{l}\text { Sum } \\
\text { Yes }\end{array}$ & & & & \\
\hline $\mathrm{BBC} 1$ & 632 & & 880 & & \\
\hline BBC 2 & 203 & & 880 & & \\
\hline BBC News & 274 & & 880 & & \\
\hline ITV News & 295 & & 880 & & \\
\hline Channel 4 & 241 & & 880 & & \\
\hline Channel 5 & 125 & & 880 & & \\
\hline Sky News & 374 & & 880 & & \\
\hline Islam Channel & 112 & & 880 & & \\
\hline Peace TV & 94 & & 880 & & \\
\hline ARY News & 182 & & 880 & & \\
\hline PTV Global & 68 & & 880 & & \\
\hline PTV Prime & 55 & & 880 & & \\
\hline
\end{tabular}

Note: ${ }^{*} p<.05 ;{ }^{* *} p<.01 ;{ }^{* * *} p<.001$. 
Table 2. Model fit for solutions ranging between one and nine classes $(N=880)$.

\begin{tabular}{lcccccc}
\hline & AIC & aBIC & BIC & $\begin{array}{c}\Delta \text { BIC } \\
(\mathrm{k}-1)-\mathrm{k}\end{array}$ & $\begin{array}{c}\text { LMR } \\
\text { Test }\end{array}$ & Entropy \\
\hline 1 Class & 10244.12 & 10263.37 & 10301.48 & --- & --- & --- \\
2 Classes & 9185.87 & 9225.98 & 9305.37 & 996.11 & $1072.08^{* * *}$ & .89 \\
3 Classes & 8972.26 & 9033.22 & 9153.90 & 151.47 & $236.92^{* *}$ & .91 \\
4 Classes & 8804.80 & 8886.61 & 9048.57 & 105.32 & $191.30^{* *}$ & .92 \\
5 Classes & 8680.08 & 8782.75 & 8986.00 & 62.57 & $149.02^{* * *}$ & .79 \\
6 Classes & 8619.13 & 8742.65 & 8987.18 & -1.19 & $85.98^{*}$ & .81 \\
7 Classes & 8561.87 & 8706.24 & 8992.06 & -4.88 & $82.33^{* *}$ & .82 \\
8 Classes & 8523.15 & 8688.37 & 9015.48 & -23.42 & $63.99^{*}$ & .83 \\
9 Classes & 8500.35 & 8686.43 & 9054.82 & -39.34 & 48.26 & .85 \\
\hline
\end{tabular}

Note: aBIC $=$ Sample-size adjusted Bayesian Information Criterion ${ }^{*} p<.05 ;{ }^{* *} p<.01 ;{ }^{* * *} p<.001$. 
Table 3. Mean (standard error) of the given outcome as a function of latent class membership.

\begin{tabular}{|c|c|c|c|c|}
\hline & \multicolumn{2}{|c|}{$\begin{array}{l}\text { Support for Terrorism } \\
\qquad(\mathrm{N}=860)\end{array}$} & \multicolumn{2}{|c|}{$\begin{array}{l}\text { Support for ISIS } \\
\qquad(\mathrm{N}=798)\end{array}$} \\
\hline & $M$ & $S E$ & $M$ & $S E$ \\
\hline Frequent Media User & $.31^{\mathrm{a}, \mathrm{b}}$ & .05 & .20 & .05 \\
\hline Infrequent Media User & $.14^{\mathrm{a}, \mathrm{c}}$ & .01 & $.15^{\mathrm{a}}$ & .01 \\
\hline Ethnic Media User & $.19 \mathrm{~d}$ & .05 & $.31 \mathrm{a}, \mathrm{b}$ & .02 \\
\hline Host Country Media User & $.10^{\mathrm{b}, \mathrm{c}, \mathrm{d}}$ & .01 & $.13^{\mathrm{b}}$ & .02 \\
\hline
\end{tabular}

Note: Means that share a superscript within the same column differed at $p<.05$. All variables were rescaled to range from 0 to 1 . 